\title{
Józef Krzywda
}

\section{Sakramentalność Kościoła a jego struktura społeczno-prawna}

Prawo Kanoniczne : kwartalnik prawno-historyczny 35/1-2, 213-224

1992

Artykuł został zdigitalizowany i opracowany do udostępnienia w internecie przez Muzeum Historii Polski w ramach prac podejmowanych na rzecz zapewnienia otwartego, powszechnego i trwałego dostępu do polskiego dorobku naukowego i kulturalnego. Artykuł jest umieszczony w kolekcji cyfrowej bazhum.muzhp.pl, gromadzącej zawartość polskich czasopism humanistycznych i społecznych.

Tekst jest udostępniony do wykorzystania w ramach dozwolonego użytku. 
KS. JÓZEF KRZYWDA, CM

\section{SAKRAMENTALNOŚĆ KOSCIOŁA A JEGO STRUKTURA SPOLECZNO-PRAWNA}

Treść: Wstęp. - 1. Kościól jako Sakrament i jego społeczno-prawny wyraz.2. Rola słowa Bożego $w$ formowaniu społeczności kościelnej. - 3. Znaczenie i funkcja sakramentów $w$ tworzeniu i doskonaleniu wspólnoty kościelnej. Zakonczenie.

\section{Wstęp}

Wyrażenie Sacramentum magnum (Ef. 5,32), którym posłużył się po raz pierwszy św. Paweł w odniesieniu do Kościoła w kontekście spraw małżeńskich, ma tu szczególną wymowę. Kościół od samego początku swego istnienia, rozważając tajemnicę swego bytu, zwłaszcza w perspektywie swego posłannictwa i celu, będzie obficie czerpał, między innymi z teologicznej intuicji i doświadczenia pawlowego; zwłaszcza będzie szukał klucza do rozwiązania i wyjaśnienia swej tajemnicy w relacji do tajemnicy Słowa Wcielonego.

Sobór Watykański II, poddając głębokiej refleksji problematykę tajemnicy Kościoła, wypracuje odnowioną definicję Kościoła, określając go: Jako „Sakrament, czyli znak i narzędzie wewnętrznego zjednoczenia z Bogiem i jedności całego rodzaju ludzkiego ${ }^{1}$.

Na tle takiej wizji Kościoła, jawi nam się wyraźniej i doskonalej idea zbawczego planu Trójcy świętej, dotyczącego sposobu uświęcania i prowadzenia ludzkości ku wyznaczonemu celowi. Kościół jako Sakrament, urzeczywistnia się przez głoszenie słowa i sprawowanie sakramentów; słowo i sakramenty stanowią $w$ ekonomii zbawienia ciągle aktualizującą się obecność Boga w świecie. Równocześnie to samo słowo Boże i te same sakramenty stwarzają zewnętrzny wymiar; widzialny kształt Kościoła; w nich bowiem znajdują się ontologiczne podstawy ${ }^{2}$ i przesłanki dla prawa kościelnego.

Uzasadnienie dla tak sformulowanego przedmiotu rozważań, który został zawarty powyżej w temacie, czerpię głównie z Konstytucji dogmatycznej o Kościele Lumen Gentium oraz z Konstytucji dogmatycznej - Objawieniu Bożym Dei Verbum, które rozwijają w sposób szczególny ideę sakramentalną Kościoła na bazie słowa Bożego i sakramentów.

1 Konst. dogm. Lumen gemtium, n. 1.

- R. Sobański, Slowo $i$ sakrament jako czynniki ksztaltujące prawo koscielne, Prawo kanoniczne 16 (1973) nr $1-2$, s. 3. 


\section{Kościól jako Sakrament i jego spoleczno-prawny wyraz}

Sobór Watykański I, w Konstytucji dogmatycznej $O$ wierze katolickiej naucza, że prawdy wiary nie mogą być poznawane inaczej jak tylko na drodze poznania analogicznego ${ }^{3}$. W tym samym sensie kontynuuje swoje nauczanie Sobór Watykański II, w szczególności w swej refleksji nad tajemnicą Kościoła; stosując wyraźną analogie między tajemnicą Wcielonego Słowa, a wcieleniem się Chrystusa w Kościoł. Tekst Konstyttucji ukazuje tę prawdę następująco: „Chrystus, jedyny Pośrednik, ustanowił swój Kościół święty, wspólnotę wiary, nadziei i miłości tu, na tej ziemi, jako widzialny organizm... Wyposażona zaś $w$ organa hierarchiczne społeczność i zarazem Mistyczne Ciało Chrystusa, widzialne zrzeszenie i wspólnota duchowa, Kościół ziemski i Kościół bogaty w dary niebiańskie - nie mogą być pojmowane jako dwie rzeczy odrębne; przeciwnie, tworzą one jedną rzeczywistość złożoną, która zrasta się z pierwiastka boskiego i ludzkiego. Dlatego też na zasadzie bliskiej analogii upadabnia sie ona do tajemnicy Stowa Wcielonego ..." 4. Cytowany tekst, jak wyraźnie zaznaczono; mówiąc 0 ,zasadzie bliskiej analogii", nie wyczerpuje ani nie wyklucza innych, możliwych sposobów poznania tajemnicy Kościoła; niemniej przybliża i uwydatnia głęboką prawdę o zjednoczeniu się Słowa Wcielonego z Kościołem, który żyje w szczególny sposób w nim przez swoje słowo i sakramentys. W tej perspektywie Kościół, jako tajemnica, jawi się nam jako jedna $z$ podstawowych rzeczywistości w planie boskiego zbawienia ludzkości, przez Chrystusa w Duchu świętym ${ }^{6}$.

Rzecz znamienna, że Sobór Watykański II, dokonując na nowo samookreślenia swej własnej tożsamości, zrezygnował $z$ funkcjonujących dotychczas klasycznych definicji: typu „społeczności doskonałej” na rzecz biblijnej; autentycznej wersji Kościoła ukazanej w całej gamie obrazów i przenośni, podkreślających wewnętrzną naturę i bogactwo darów Bożych. Idąc za Konstytucją dogmatyczną o Kościele, przypomnijmy niektóre $z$ nich: „Kościół jako owczarnia, której bramą jedyną i konieczną jest Chrystus (J. 10, 1-10); „rola uprawna” (1 Kor. 3,9); „Winnica wybrana" (Mt. 21, 33-43); „Winorośl” (J. 15, 1-5); ,Budowla Boża” (1. Kor. 3, 9); „Przybytek Boga z Ludźmi” (ap. 21, 3); „Świątynia

${ }^{3}$ Concilium Vaticanum I, Constitutio dogmatica de fide catholica, Seria III, $(24,04 / 970)$, caput IV, De fide et ratione, in Conciliorum Oecumenicorum Decreta, Bologna $1973^{3}$, s. 808.

- Lumen gentium, n. 8, Sobór Watykański drugi, Konstytucje, dekrety, deklaracje (tekst lacińsko-polski), Paris 1967. (Dalsze cytaty w obecnym artykule zostały zaczerpnięte $z$ tegoż zbioru). s. 29 .

5 J. B. Beyer, Il codice del Vaticano II, dal Concilio al Codice, Bologna 1984,

- Lumen gentium, n. 6; W. Bertrams, De natura iuris Ecclesiae proprii notanda, in Periodica de re morali canonica liturgica 66 (1977) 3-4, s. 570; J. B. Beyer, dz. cyt., s. 29; R. Sobański, Model Kościola tajemnicy, jako podstawa teorii prawa kościelnego, Prawo kanoniczne 21 (1978) $\mathrm{nr} 1-2$, s. 48. 
święta” (1 P. 2, 5); „Matka nasza” (Gal. 4, 26). Te i inne figury Kościoła, ukazując jego wewnętrzną naturę, jednocześnie konsekwentnie kreślą charakter jego posłannictwa i właściwy mu cel, dla którego został założony ${ }^{7}$. Niewątpliwie, fakt zestawienia kolejno szeregu obrazów dotyczących Kościoła, stanowi wyraźną próbę jaką podjął Sobór, aby nam przybliżyć niezglębione bogactwo wewnętrzne życia Kościoła ${ }^{8}$.

Tajemnica pozostanie jednak zawsze tajemnicą. Kościół jest dzielem Boga; jest zanurzony w Bogu. Tak, jak On sam pozostaje nieogarniony w swej istocie, podobnie Kościół, jako Jego dzieło, pozostaje nadal w swej najgłębszej warstwie tajemnicą.

Nie posiadamy ciągle jeszcze, powie pap. Paweł VI, w swym przemówieniu inauguracyjnym otwierającym drugą sesję Soboru, pełnego zadowalającego pojęcia Kościoła. Kościól, podkreśli Ojciec św., będąc tajemnicą obecności Boga, jest tej natury, że dopuszcza w tej materii ciągle nowe badania $\mathrm{i}$ poszukiwania ${ }^{9}$. $\mathrm{Z}$ okazji międzynarodowego kongresu w Mediolanie, jeszcze raz nawiąże do tego samego tematu, stwierdzając: ...Konstytucja Kościcła, jest zarazem: duchowa i instytucjonalna; Kościół jest tajemnicą zbawienia w wymiarze widzialnym, ukonstytuowany w prawdziwą ludzką społeczność, która wyraża swą obecność we właściwej sobie formie, w działalności wewnętrznej i zewnętrznej. W ten sposób w Kościele, który jest społecznością Bosko-ludzką, należący do niej członkowie, włączeni w Lud Boży łączą się z Chrystutem a w Nim z Bogiem, aby $w$ ten sposób dostąpić zbawienia. Duch święty, który jest w nim obecny ujawnia się we wszechstronnym działaniu; przez jego twórczą działalność, Kościół-instytucja, jest tym samym wewnętrznie duchowy, nadprzyrodzony ${ }^{10}$. Ideę tę $w$ sposób syntetyczny wyraża

${ }^{7}$ Lumen gentium, n. 6; A. Pompei, Eucharistica celebratio Ecclesiae aedificatio, Monitor ecclesiasticus 51 (1976) 35 .

\& Lumen gentium, nn. 6, 7; M. Stasiak, Teologiczne podstawy nowego kodeksu prawa kanonicznego wedlug Konstytucji Sacrae disciplinae leges, Roczniki teologiczno-Kanoniczne, t. 31 (1984), z. 5 , s. 86.

- Paulus VI, Allocutio in altera Concilii Decumenici Vaticani II, sessione ineunda: AAS 55 (1963) 848; zob.: X. Ochoa, Leges Ecclesiae post Codicem Iuris Canonici ceditae, vol. III, col. 4402, n. 3130, Roma 1972: „Mirum non est, inquimus, si vera, suprema ac plena notio Ecclesiae qualem Christus condidit et Apostoli aedificare coeperunt, adhuc accuratione enuntiatione indiget. Nam Ecclesiae mysterium est, scillicet arcana res quae Dei praesentia penitus perfunditur, ac propterea talis est naturae, quae novas semper altioresque seipsius explorationes admittat".

${ }_{10}$ Paulus VI, Allocutio iis qui interfuerunt Conventui internationali secundo iuris canonici Mediolani habito: De sensu iuris canonici in Ecclesia sub lace theologiae et ecclesiologiae actualis, X. Ochoa, Leges Ecclesiae, dz. cyt., vol. V, col. 6653, n. 4221: „...la Costituzione della Chiesa è insieme pneumatica e istituzionale: la Chiesa è mistero di salvezza reso visible dalla sua costituzione di vera società umana e dalla sua attività nell a sfera esterna. In tal modo, nella Chiesa, come unione sociale umana, gli uomini si uniscono in Christo e, per mezzo di Lui, con Dio, ragiungendo cosi la salvezza; e lo Spirito santo è in essa presente e operante in tutta l'estensione della vita di lei. Vale a dire che la Chiesa-istituzione è allo stesso tempo intrisecamente spirituale, soprannaturale"; $\mathrm{F}$. Urbano, Natura iuris canonici, in PRMCL 66 (1977) 3-4, s. 683-685. 
Sobór, stwierdzając, że Kościół jest: „ustanowiony i zorganizowany na tym świecie, jako społeczność, trwa w Kościele katolickim, rządzonym przez następcę Piotra oraz biskupów pozostających $z$ nim we wspólnocie (communio)..." 11 .

Obydwie plaszczyzny: duchowa i instytucjonalna zcalone w jedno dla realizacji duchowego celu, zostaly wyznaczone i naznaczone poslannictwem samego założyciela Kościoła, Chrystusa. Powołanie to i posłannictwo zarazem, w swej zasadniczej warstwie: słowa i sakramentów, stanowi rzeczywistość konstytuującą Kościół a jednocześnie sprawiającą to, że jest on instytucją jedyną w swoim rodzaju i niepowtarzalną. W związku z tym, Kościól jako taki, z tytułu swego boskiego pochodzenia, swej szczególnej natury, traktuje swoje powołanie i swoje posłannictwo jako własne $\mathrm{i}$ niezbywalne prawo, a jednocześnie jako obowiązek realizacji otrzymanego mandatu: „Idźcie i nauczajcie wszystkie narody, udzielając im chrztu w imię Ojca i Syna i Ducha świętego" (Mt. 28, 19); jednocześnie otrzymał Kościół prawo, zawarte przynajmniej implicite, $\mathrm{w}$ treści mandatu, używania właściwych mu środków i form przekazu depozytu wiary w sposób niezależny od jakiejkolwiek władzy świeckiej ${ }^{12}$.

Niech zatem nie dziwi fakt, że Kościół mając na względzie swą szczególną misję do wypełnienia, określa i stanowi własną konstytucję, swoje własne prawo $\mathrm{i}$ organizuje odpowiednie do jego natury i celu struktury i instytucje społeczno-publiczne ${ }^{13}$. Idee te zostały szczególnie wyraźnie zaakcentowane, przez Jana Pawła II, w Konstytucji apostolskiej Sacrae disciplinae leges: Narzędzie jakim jest Kodeks, stwierdza papież, w pełni zgadza się $z$ naturą Kościoła, jaką zwłaszcza przedstawia nauka Soboru Watykańskiego II, brana $w$ całości, $z$ szczególnym uwzględnieniem doktryny eklezjologicznej. Zatem w jakiś sposób ten nowy Kodeks może być pojmowany jako wielki pas transmisyjny przenoszący na język kanonistyczny tę doktrynę, mianowicie soborową eklezjologię ${ }^{14}$. Aby rozproszyć niepokoje pojawiające się w pewnych środowiskach, wyjaśnia, że celem Kodeksu bynajmniej nie jest zastąpienie w życiu Kościoła lub wiernych wiary, łaski, charyzmatów a zwłaszcza miłości. Przeciwnie, w Kodeksie chodzi raczej o to, aby rodził taki porządek społeczności kościelnej, który przyznając główne miejsce miłości, łasce i charyzmatom, jednocześnie ułatwiałby ich uporządkowany postęp w życiu czy to spoleczności kościelnej, czy to poszczególnych ludzi, którzy do niej należą ${ }^{15}$.

11 Lumen gentium, n. 8: K. Walf, Kirchenrecht, Düsseldorg 1984, s. 20-21.

12 Lumen gentium, n. 7; G. Cardia, Il governo della Chiesa, Bologna 1984, s. $12-13$.

${ }_{13} \mathrm{~W}$. Bertrams, Un approcio sistematico, in La Collegialità episcopale, tra teologia e diritto canonico (sotto la direzione di Giamperro Mazzoni), Bologna 1968, s. 100; G. Cardia, dz. cyt., s. 13.

14 Const. Ap. Jana Pawła II, Sacrae disciplinae leges, Codex Iuris Canonici auctoritate Joannis Pauli PP. II promulgatus, Libreria Editrice Vaticana 1989, s. XVII.

is tamże, s. XVI. 


\section{Rola słowa Bożego w formowaniu społeczności kościelnej}

W sensie biblijnym: słowo, posiada dwie szczególne cechy: po pierwsze, wiąże się ono tak ściśle $z$ rzeczywistością, że niemal się $z$ nią utożsamia; słowo dabar, oznacza zarówno słowo w znaczeniu opowiadania, polecenia, jak i samą rzecz czy sprawę. Słowo wiąże się równie ściśle z działaniem: w sensie biblijnym mówić, znaczy wręcz działać; co szczególnie jest aktualne w odniesieniu do Boga, który stwarza przez słowo; słowo Boże powoduje to, co wypowiada (Ps. 33, 9); (Mdr. 9, 1); (Iz. 55, 10). Tak jest ze słowem Chrystusa, które jest skierowane do tych, którzy Go słuchają i którzy muszą zająć wobec Niego takie czy inne stanowisko: za lub przeciw Niemu (Mt. 7, 24-27; 13, 23) ${ }^{16}$.

Kościól otrzymal słowo od Pana. Słowo to, Kościół przechowywał od początku $z$ najwyższym pietyzmem a jednocześnie obficie nim szafuje.

Konstytucja dogmatyczna, O Objawieniu Bożym Dei Verbum ${ }^{17}$, przypomina tradycyjną naukę Kościoła o wartáści i znaczeniu słowa Bożego w historii zbawienia; specjalnie zwraca uwagę przy tym, na jego szczególną moc i skuteczność w czasie, który otwiera Orędzie tego słowa w Nowym Przymierzu, co znalazło szczególne podkreślenie w słowach Apostoła: „tajemnica ta nie została oznajmiona innym pokoleniom tak, jak teraz objawiona została w Duchu świętym jego świętym Apostołom i Prorokom (Ef. 3, 4-6), aby głosili Ewangelię, wzbudzali wiarę w Jezusa Chrystusa i Pana oraz zgromadzali Kościól" 18 .

Słowo to, które posiada wewnętrzną, tajemniczą dynamikę, jak ziarno (Mt. 13,1-16), realizuje swoje przeznaczenie wtenczas, kiedy natrafia na odpowiedni grunt; zostaje wówczas przyjęte i powoduje odpowiedź w formie słowa lub czynu; i wówczas przekształca się w dialog 19 .

Dialog spowodowany slowem nabiera nowego znaczenia i nowego wymiaru, jeśli jest wyrażany społecznie; przybierając różne formy publicznego świadectwa. Albowiem, jak naucza Sobór: „....podobało się jednak Bogu uświęcać i zbawiać ludzi nie pojedynczo, z wykluczeniem wszelkiej wzajemnej między nimi więzi, lecz uczynić $z$ nich lud, który by Go poznawał w prawdzie i święcie Mu służyl" ${ }^{20}$.

To właśnie dzięki słowu, jednoczy się Lud Boży. Bóg troszczy się po ojcowsku o wszystko; chciał, aby wszyscy ludzie tworzyli jedną rodzinę

16 L. Dufour, Slownik Nowego Testamentu (przekład i opracowanie polskie, Bp. K. Romaniuk), Poznań 1986, s. 570-571.

17 AAS 58 (1966) 817-835.

18 Konst. dogm. O Objawieniu Bożym Dei Verbum, n. 17.

19 J. Ratzinger, La festa della fede, Milano 1984, s. 19; B. Rega ux, Kommentar zum $V$ Kapitel der dogmatische Konstitution über die göttliche Offenbarung, in Lexikon für Theologie und Kirche, Freiburg-bassel-Wien 1967, s. 565; R. Sobański, Model Kościola-tajemnicy jako podstawa teorii prawa kościelnego, Prawo Kanoniczne 21 (1978) nr 1-2, s. 54.

${ }^{20}$ Lumen gentium, n. 9. 
i odnosili się do siebie wzajemnie $w$ duchu braterskim ${ }^{21}$. Braterstwo, jeśli nie ma pozostać li tylko hasłem sloganowym, musi się opierać na solidnych podstawach prawdy, sprawiedliwości i miłości, które to wartości stanowią zasadniczą treść przesłania zawartego w słowie Bożym. Niemożna jednak zapomnieć, co stanowi problem praktyczny przekazu Dobrej Nowiny przy pomocy słowa, że jedynie prawda przekazywana w miłości, może być skuteczna i przynosi spodziewane owoce ${ }^{22}$; tylko prawda przekazywana metodą milości może pretendować do miana ewangelicznego świadectwa. W tym duchu pełnili swoje posłannictwo Apostolowie, w takim duchu kontynuuje swoje posłannictwo Kościół, który widzi, zwłaszcza w Zgromadzeniu liturgicznym, najwyższy wyraz i manifestację zjednoczenia wiernych w Duchu świętym. Wierni bowiem naznaczeni znamieniem sakramentalnym chrztu świętego, dzięki wierze i miłości, gromadzą się wspólnie, aby sprawować Eucharystię; aby słuchać słowa Bożego; aby w zjednoczeniu z całym Ludem Bożym składać należne uwielbienie Bogu. Dlatego słusznie Liturgia święta nazywana jest: „szczytem, do którego zmierza działalność Kościoła i jednocześnie jest źródłem, z którego wypływa cala jego moc" ${ }^{23}$.

Ponieważ przez apostolskie przepowiadanie Ewangelii, Lud Boży, jest zwoływany i zgromadzany tak, że wszyscy należący do tego Ludu, będąc uświęcani przez Ducha świętego, ofiarują samych siebie jako „ofiarę żywą, świętą i miłą Bogu" (Rz. 12,1) ${ }^{24}$, jest rzeczą oczywistą, ̇̇e czynności liturgiczne, „nie są czynnościami prywatnymi, lecz kultem Kościoła, będącego „Sakramentem jedności”, a Kościół to Lud święty, zjednoczony i zorganizowany pod zwierzchnictwem biskupów ${ }^{25}$. Mając to wszystko na względzie, stwierdza Konstytucja o świętej Liturgii: „czynności liturgiczne należą do całego Kościoła" 26 .

Cecha jednocząca mocy słowa Bożego zostanie szczególnie wyraźnie uwydatniona i usankcjonowana w nowym Kodeksie. Kan. 762, który otwiera problematykę przepowiadania słowa Bożego, ujmuje to następująco: „Ponieważ Lud Boży, jednoczy się przede wszystkim przez słowo Boga żywego, którego $z$ całą słusznością można się domagać $z$ ust kapłańskich, stąd święci szafarze winni bardzo cenić posługe przepowiadania, ponieważ ich podstawowym obowiązkiem jest głoszenie wszystkim Ewangelii Bożej" 27.

Okolicznością szczególnie sprzyjającą głoszeniu i przyjęciu słowa Bożego jest gromadzenie się Ludu Bożego na sprawowanie Liturgii świętej, która

21 Konst. duszp. O Kościele w świecie współczesnym Gaudium et spes, n. 24; Jan Pawet II, Enc. Redemptor Hominis, n. 13.

${ }_{22} \mathrm{R}$. Sobański, De theologicis et sociologicis praemissis theoriae iuris ecclesialis eleborandae, PRMCL 66 (1977) 3-4, s. 667.

${ }^{23}$ Konst. O świętej Liturgii Sacrosanctum Concilium, n. 10.

24 Dekret O Posludze i życiu kaplańskim, Presbyterorum Ordinis, n. 2.

25 Sacrosanctum Concilium, n. 26.

26 tamże

27 Kan. 762 (KPK) 1983 
jest aktem kultu całego Kościoła ${ }^{28}$. Właśnie w czasie Eucharystii gloszenie slowa Bożego, pełni rolę ,,szczególnego środka” budowania i umacniania społeczności kościelnej.

Wśród wielu innych form, pierwsze miejsce prawodawca przyznaje słusznie homilii, która jak mówi kan. 767 § 1: „Stanowi ona część samej liturgii i jest zarezerwowana kapłanowi lub diakonowi..." 29, którzy z tytułu szczególnej funkcji szafarza Eucharystii pelnią tu i teraz wobec zgromadzonego Ludu Bożego rolę świadków obecności Pana.

Rozważając zagadnienie wpływu słowa Bożego na kształtowanie spoleczności kościelnej, poważną i swoistą rolę należy przyznać $w$ tym zakresie prawu kościelnemu, jako prawu, które pełni tu funkcję narzędzia przekazu: zasad i norm, opartych przecież na przesłaniu ewangelicznym i czerpiącym w nim moralną siłe przekazu wiary, prawdy i miłości. Działalność prawodawcza oraz nauka prawa kościelnego jest niewątpliwie jedną $\mathrm{z}$ form przepowiadania Ewangelii: porządek bowiem miłości jest podstawowym porządkiem na którym opiera się całe przepowiadanie Ewangelii dla budowania wspólnot ${ }^{30}$, a co za tym idzie calego Kościoła a w dalszej perspektywie, świata.

Należy przyznać rację tym, którzy twierdzą, że polem działalności prawa są zasadniczo stosunki społeczne, a więc regulacja sfery zewnętrznej społeczności ludzkiej; budowanie struktur życia wspólnotowego. Mając jednak na uwadze ten oczywisty fakt, że życie zewnętrzne we wszelkich jego przejawach świadomych i zorganizowanych jest ściśle powiązane i zależy od treści życia duchowego i moralnego poszczególnych ludzi oraz branych zbiorowo, nie podlega żadnej kwestii, że prawo interesuje się $\mathrm{i}$ rozstrzyga problemy życia ludzi $w$ obydwu zakresach lącznie. Zadaniem bowiem prawa jest: wzmacniać, ale też wspierać te elementy i czynniki, które integrują społeczność od wewnątrz ${ }^{31}$.

Prawo kościelne zatem, ustalając konkretne normy dotyczące, między innymi posługi przepowiadania słowa, pełni wybitnie rolę służebną w dziele budowania wspólnoty kościelnej.

\section{Znaczenie i funkcja sakramentów $w$ tworzeniu i doskonaleniu wspolnoty kościelnej}

Sakramenty stanowią zasadniczą tkankę życia i świętości Kościoła. Prawdę tę raz jeszcze przypomina nauczanie Soboru Watykańskiego II. Zwlaszcza znamienne w tym względzie są słowa Konstytucji o Świętej Liturgii, gdzie czytamy: „Celem sakramentów jest uświęcenie człowieka, budowania Mistycznego Ciała Chrystusa, a wreszcie oddawanie czci

\footnotetext{
28 Sacrosanctum Concilium, n. 26.

${ }^{29}$ Kan. 767 (KPK) 1983.

so R. Sobański, Iura propter officia, Prawo Kanoniczne 29 (1986) nr 3-4, s. $11-12$.

31 tamże.
} 
Bogu" 32. Nie można nie zauważyć, zwlaszcza $z$ punktu widzenia tekstu kanonu 840 Kodeksu, pewnej niedoskonałości sformułowania zawartego w Konstytucji.

Tę, być może, niedostrzeżoną lukę, doskonale uzupełnia zapis wspomnianego wyżej kan. 840, w którym otrzymujemy najpierw gruntownie uzasadnioną teologicznie definicję sakramentów; po czym następuje mocno uwydatniony fakt ścisłej lączności - zespolenia Chrystusa z Kościołem w akcie sakramentu i $\mathrm{w}$ końcu podkreśla się szczególny wpływ sakramentów na formowanie się wspólnoty kościelnej.

Sakramenty Nowego Testamentu, stwierdza kan. 840 KPK, są czynnościami Chrystusa i Kościoła, są znakami oraz środkami przez które wyraża się i wzmacnia wiara, poprzez które oddaje się kult Bogu oraz dokonuje się uświęcenie człowieka. Dlatego właśnie, w najwyższym stopniu przyczyniają się one do wprowadzenia do wspólnoty kościelnej oraz do zamanifestowania i umocnienia jej obecności ${ }^{33}$.

Wspólnota kościelna zatem; jej istnienie, wewnętrzna dynamika i rozwój, bezpośrednio zależą od aktualizowania się sakramentów w Kościele. Przez sakramenty Kościół trwa, a jednocześnie odradza się ciągle na nowo; staje się bardziej Kościołem - Wspólnotą: zakorzenioną w jednym chrzcie, wzmacnianą coraz szerszym uczestnictwem $w$ innych sakramentach a zwłaszcza w Eucharystii ${ }^{34}$.

Jeśli przyjrzeć się bliżej strukturze i działaniu poszczególnych sakramentów, nietrudno zauważyć, prócz warstwy religijnej, czysto duchowej, który jest przedmiotem wiary Kościoła, ich aspekt wspólnototwórczy:

Chrzest święty, nazwany bramą sakramentów, włącza nowoochrzczonego do Kościoła (kan. 849); stając się członkiem Kościoła, chrześcijanin $\mathrm{w}$ miare poszerzania swych relacji ze społecznością wiernych, poszerza zakres swych uprawnień oraz zaciąga względem niej coraz to nowe zobowiązania, z których wyznawanie otrzymanej wiary od Boga za pośrednictwem Kościoła, staje się pierwszym i najważniejszym $z$ obowiązków ${ }^{35}$.

Uczestnictwo $\mathrm{w}$ kulcie Bożym, w którym chrześcijanin wyraża publicznie swoją przynależność do Kościoła, ma swoje źródło w sakramencie chrztu, przez który następuje: „wszczepienie w paschalne misterium Chrystusa" ${ }^{36}$. Tak więc, chrzest przyjmowany przez człowieka, w jednym

32 Sacrosanctum Concilium, n. 59.

33 Kan. 840 KPK/1983: „Sacramenta Novi Testamenti, a. Christo Domino instituta et Ecclesiae concredita, utpote actiones Christi et Ecclesiae, signa extant ac media quibus fides exprimitur et roboratur, cultus Deo redditur et hominum sanctificatio efficitur, atque ideo ad communionem ecclesiasticam inducendam firmandam et manifestandam summopere conferunt; quapropter in is celebrandis summa veneratione debitaque diligentia uti debent tum sacri ministri tum ceteri christifideles".

${ }_{34} \mathrm{~T}$. J. Jimenez-Urresti, Ontologia a wspólnoty $i$ struktury kolegialne w Kościele, Concilium 1-10 (1965), Poznań-Warszawa 1968, s. 605; A. Pompei, dz. cyt., s. 37 ; R. Sobański, Slowo $i$ Sakrament, dz. cyt., s. 8.

${ }_{35}$ Lumen gentium, n. 11.

${ }^{6}$ Sacrosanctum Concilium, n. 6. 
i tym samym akcie, powoduje i sprowadza określone skutki duchowe, a jednocześnie pelni funkcje konstytuującą Kościól, włączając ochrzczonego do wspólnoty wierzących ${ }^{37}$. Wspólnota kościelna wyraża się $w$ sposób doskonały w kulcie publicznym Kościoła; przede wszystkim zaś w Zgromadzeniu eucharystycznym, w którym udzial chrześcijanina urasta do rangi powinności wobec Boga i względem wspólnoty kościelnej, do której należy ${ }^{38}$. Właśnie podczas sprawowania Najświętszej Ofiary, dokonuje się umocnienie wiary otrzymanej na chrzcie świętym; tutaj wierni karmią się słowem Pisma świętego; tutaj wreszcie odnawia się zobowiązania płynące z przyjęcia wiary. Podczas Eucharystii wierni posilają się w Komunii świętej Ciałem Chrystusa $\mathrm{i} w$ ten sposób wyraźnie $\mathrm{i}$ konkretnie manifestują jedność Ludu Bożego, której „stosownym znakiem i cudowną przyczyną jest ten Najświętszy Sakrament" ${ }^{39}$. Bez Eucharystii nie tylko nie można sobie wyobrazić prawdziwej wspólnoty wierzących, lecz, jak to stwierdza dekret „O posludze i życiu kapłańskim”: „....̇̇adna społeczność chrześcijańska nie mogłaby być zbudowana, gdyby nie miała korzenia i podstawy w sprawowaniu Najświętszej Eucharystii" ${ }^{40}$. Prawdę tę prawodawca usankcjonuje w kan. 897 obecnego Kodeksu. Ofiara eucharystyczna, czytamy: „oznacza i sprawia jedność Ludu Bożego, przez nią buduje się Ciało Chrystusa. Pozostałe bowiem sakramenty i wszystkie kościelne dzieła apostolatu mają związek z Najświętszą Eucharystią i ku Niej są ukierunkowane" "11.

Sakrament bierzmowania ma ścisły związek z sakramentem chrztu świętego, o czym wyraźnie przypomina Konstytucja o Świętej Liturgii (n. 71) ${ }^{42}$. Tutaj znajdujemy również, właśnie $z$ racji ścisłej łączności obydwu sakramentów, uwagę, aby obrzęd bierzmowania ująć i rozpatrzyć w taki sposób, aby został jasno ukazany związek tego sakramentu $z$ całym wtajemniczeniem chrześcijańskim. Dlatego też postuluje się, aby przyjmowanie tego sakramentu bylo poprzedzone odnowieniem przyrzeczeń złożonych na chrzcie świętym. Wierni bowiem utwierdzeni mocą tego sakramentu przez Ducha świętego są przeznaczeni do apostolstwa przez samego Pana ${ }^{43}$.

Dzięki temu darowi Ducha świętego, ochrzczeni doskonalej łączą się z Kościołem, zostają wzmocnieni w przyjętych zobowiązaniach, by słowem i czynem dawać świadectwo o Chrystucie, przez szerzenie i obronę wiary (kan. 879).

37 tamże

38 P. A. Bonnet, Eucharistia et ius, PRMCL 66 (1977) 59; T. G. Barberena, Sakramenty w Prawie kanonicznym, Concilium 1-10 (1968), Poznań-Warszawa 1969, s. 419; R. Sobański, Stowo $i$ Sakrament, dz. cyt., s. 8.

${ }^{30}$ Lumen gentium, n. 11; Paulus VI, Enc. Mysterium fidei, AAS 57 (1965) $770-772$.

${ }^{40}$ Presbyterorum ordinis, n. 6.

4 Kan. 897 KPK/1983.

12 Sacrosanctum Concilium, n. 71 .

13 tamże 
Sakrament pokuty sprawia nie tylko przebaczenie grzechów i pojednanie $z$ Bogiem, ale niesie $z$ sobą także pojednanie $z$ Kościołem, któremu grzeszący zadali ranę ${ }^{4}$. Przebaczenie jest aktem miłości i miłosierdzia zarazem; które jednocześnie przywracają: utraconą relację między człowiekiem a Bogiem; uzdrawiając relacje między czlowiekiem a Kościołem, tym samym umacniają i utrwalają więzi społeczne między ludźmi.

Sakrament namaszczenia chorych zajmuje również szczególne miejsce wśród sakramentów. I w nim, nie można nie widzieć aspektu wspólnoto-twórczego. W sakramencie namaszczenia chorych, więż chorego z Kościołem nabiera znamion szczególnej, obopólnej wierności duchowej. Kościół zachęca usilnie chorych aby nabrali otuchy i ufności i przyjęli chorobę i śmierć w łączności z męką i śmiercią Chrystusa, gdyż cały Kościół poleca ich cierpiącemu i uwielbionemu Panu, aby ich zbawił ${ }^{45}$; owszem, Kościól zachęca ich również, by łącząc się dobrowolnie z męką i śmiercią Chrystusa, przysparzali dobra Ludowi Bożemu ${ }^{46}$.

Pozostałe dwa sakramenty: kapłaństwo i małżeństwo, każdy zgodnie ze swą specyficzną strukturą i przeznaczeniem, w sposób wybitny przyczyniają się do wzrostu i doskonalenia się Kościoła na płaszczyźnie życia wspólnotowego.

Dekret o pasterskich zadaniach biskupów $w$ Kościele ${ }^{47}$, już choćby w tytule dokumentu, zawiera ideę głównego posłannictwa, które $\mathrm{z}$ natury swojej posiada wymiar wspólnotowy. Biskupi, czytamy w Dekrecie, którzy dzielą troskę o wszystkie Kościoly, pełnią swoje biskupie posługiwanie $i$ swe zadania, otrzymane przez konsekrację biskupią, w łączności i pod zwierzchnictwem papieża. W swym urzędzie nauczycielskim i w pasterzowaniu, złączeni są w stosunku do całego Kościoła Bożego w jedno Kolegium, czyli ciało ${ }^{48}$. Jeśli chodzi 0 prezbiterów, to Sobór Watykański II, nazywa ich „koniecznymi pomocnikami i doradcami w posłudze i obowiązku nauczania, uświęcania i rządzenia Ludem Bożym ${ }^{49}$. Wniosek: jedni i drudzy wezwani są, wedle uczestnictwa w kapłaństwie Chrystusa, do wspólnej, skoordynowanej działalności apostolskiej w celu budowania Kościoła - Wspólnoty Ludu Bożego.

Co się tyczy sakramentu małżeństwa, któremu Kościół słusznie poświęcił wiele uwagi na Soborze Watykańskim II, trzeba zauważyć, że szczególnie mocno podkreślił, właśnie aspekt wspólnototwórczy małżeństwa. Pod n. 47 Konstytucji duszpasterskiej o Kościele w świecie

44 Lumen gentium, n. 11; Presbyterorum oridinis, n. 5; zob. kan. 959 KPK/1983.

15 Lumen gentium, n. 11; T. G. Barberena, Sakramenty w prawie kanonicznym, dz. cyt., s. 410 .

46 tamże

17 Dekret o pasterskich zadaniach biskupów w Kościele, Christus Dominus, AAS 58 (1966) 673-701.

${ }^{4}$ tamże, n. 4; J. B. Beyer, Il Codice del Vaticano II, dz. cyt., s. 40-41; C. Cardia, $I l$ governo... dz. cyt., s. 22-24; H. Müller, Das Sakrament der Weihe $\$ 79$, die Ordination in Handbuch des katholisches Kirchenrechts, regensburg 1983, s. 715-716.

49 Presbyterorum ordinis, n. 7. 
współczesnym znajdujemy znamienne $w$ tym względzie zdanie: ,....Zdrowie osoby i społeczności ludzkiej oraz chrześcijańskiej wiąże się ściśle $z$ pomyślną sytuacją wspólnoty małżeńskiej i rodzinnej" " ${ }^{0}$. Przez miłość małżonków, kontynuuje dokument, przez szlachetną płodność, jedność i wierność jak i przez współpracę przepojoną miłością wszystkich członków, chrześcijańska rodzina, ujawniać będzie wszystkim żywą obecność Zbawiciela w świecie oraz prawdziwą naturę Kościoła ${ }^{51}$.

\section{Zakończenie}

Poruszone zagadnienie wykracza daleko poza sformulowany w temacie problem. Temat słowa i sakramentu; dwóch podstawowych rzeczywistości Kościoła, posiada wymiar tajemnicy, stąd jego niezmierzone bogactwo w relacjach Bóg-czlowiek; Bóg-Wspólnota ludzka.

Faktem podstawowym dla człowieka jest przyjęcie sakramentu chrztu świętego, przez co zmienia się jego istotna pozycja w świecie a jednocześnie otwiera się przed nim nowa perspektywa: nowego życia w Bogu i w Kościele. Słowo i sakrament będą odtąd dla niego przede wszystkim źródłem życia duchowego, ale nie tylko. To samo slowo Boże i te same sakramenty zawierają w sobie element wspólnototwórczy: nowoochrzczony zostaje wraz z calym uposażeniem duchowym usytuowany w nowej społeczności ukonstytuowanej właśnie na podstawie słowa i sakramentu. Albowiem Słowo Boże i sakramenty święte zawierają w sobie wewnętrzną moc tak dla uświęcenia jednostek ludzkich, jak też dla tworzenia i organizowania odpowiednich struktur życia społecznego i wspólnotowego dla realizacji zadań i obowiązków w ramach misji, jaką otrzymał Kościół od swego Założyciela, Chrystusa. W ten sposób spełnia się odwieczny zamysł Boży tak trafnie wyrażony przez Sobór Watykański II, w Konstytucji dogmatycznej o Kościele, mianowicie: że ,... podobało się jednak Bogu uświęcać i zbawiać ludzi nie pojedynczo, z wykluczeniem wszelkiej wzajemnej między nimi więzi, lecz uczynił $z$ nich ludzi, który by Go poznawał w prawdzie $i$ święcie Mu służyl" ${ }^{52}$.

\section{Les éléments qui décident de la Sacramentalité de l'Eglise et de ses structures sociaux-juridiques}

Le problème qui se pose ici c'est de présenter l'Eglise d'une part en tant qu'un mystère, d'autre part qu'un être dans ses dimensions sociaux-juridiques.

C'est un fait que l'Eglise est basée sur la parole de Dieu et à la base de sacrements. C'est en vertu de la parole de Dieu et des sacraments que l'Eglise existe

so Gaudium et spes, n. 47; Adhort. Ap. Familiaris Consortio, 22 XI 1981, n. 15, AAS 74 (1982) 81 .

51 Gaudium ef spes, n. 48; T. Pawluk, Prawo kanoniczne wedlug Kodeksu Jana Pawla II, Prawo matżeriskie, t. III, Olsztyn 1984, s. 21-22; M. Ż u rowski, Kanoniczne prawo malzeniskie Kościola katolickiego, Katowice 1987, s. 42.

52 Lumen gentium, n. 9. 
et realise toute sa mission salvifique. Mais c'est vrai aussi que la même force interièure qui rèside en parole de Dieu et dans les sacrements est prevue et déstinée à organiser et à former toutes les structures de la vie sociale de l'Eglise pour promouvouare ladite vie communautaire, c'est-à-dire son activité exterièure.

A juste titre, peut-on le dire, que le can. $840 \mathrm{CIC} / 1983$ bien illustre la question posée: „Les sacrements du Nouveau Testament institués par le Christ Seigneur et confiés à l'Eglise, en tant qu'actions du Christ et de l'Eglise, sont des signes et moyens par lesquels la foi s'exprime et se fortifie, le culte est rendu à Dieu et se réalise la sanctification des hommes; c'est pourquoi ils contribuent largement à créer, affermir et manifester la communion ecclésiastique; aussi, dans la célébration des sacrements, tant les ministres sacrés que les autres fidèles doivent-ils agir avec une très grande vénération et avec le soin requis".

On a seulement touché ce-problème là. Il y a encore beaucoup de questions à poser en matière à venir. 